\title{
Film Review: First They Killed My Father: A Daughter of Cambodia Remembers
}

Timothy Williams

University of Marburg

Follow this and additional works at: https://digitalcommons.usf.edu/gsp

\section{Recommended Citation}

Williams, Timothy (2018) "Film Review: First They Killed My Father: A Daughter of Cambodia Remembers," Genocide Studies and Prevention: An International Journal: Vol. 12: Iss. 1: 113-114.

DOI:

https://doi.org/10.5038/1911-9933.12.1.1595

Available at: https://digitalcommons.usf.edu/gsp/vol12/iss1/14

This Film Review is brought to you for free and open access by the Open Access Journals at Digital Commons @ University of South Florida. It has been accepted for inclusion in Genocide Studies and Prevention: An International Journal by an authorized editor of Digital Commons @ University of South Florida. For more information, please contact digitalcommons@usf.edu. 


\title{
Film Review: First They Killed My Father: A Daughter of Cambodia Remembers
}

\author{
Timothy Williams \\ Centre for Conflict Studies, University of Marburg \\ Marburg, Germany
}

First They Killed My Father: A Daughter of Cambodia Remembers

Director: Angelina Jolie

Cambodia, United States, 2017

Reviewed by Timothy Williams

Centre for Conflict Studies,

Marburg University

This is the first major filmic intervention dealing with the genocide by the Khmer Rouge in Cambodia in the late 1970s since Roland Joffe's The Killing Fields in $1984^{1}$ and will likely reach an even broader audience through its distribution on the online streaming platform Netflix. As such, the film will likely play an important role in the way the genocide is remembered internationally. The audio of the film is in Khmer with sprinklings of French, subtitled in English (and other languages), and this suggests a degree of authenticity. Indeed, the film succeeds in capturing the everyday experiences of people living under the Khmer Rouge regime.

The film tells the story of Ung Loung who was a young girl living under the Khmer Rouge and who co-wrote the script with the film's director Angelina Jolie. The film begins during the Vietnam War with images of the United States of America's bombing of Cambodia and the horrific consequences for the population. This beginning is significant as it explains to an audience, who for the most part will be new to Cambodian history, the complicity of the United States in destabilising the country and preparing the ground for the Khmer Rouge to become so strong. This focus on these dynamics on the fringe of the Vietnam War do, however, neglect political dynamics within the country itself, including the civil war which started five years prior to the fall of Phnom Penh and the key role of the country's king Sihanouk in appealing to his subjects to support the Khmer Rouge. These are important factors which should have at least featured briefly to highlight that Cambodia is not just a victim of global dynamics but that the Khmer Rouge regime for the most part is based on factors that are home-grown.

The plot itself first introduces Loung and her family, her father being a military officer and the family belonging to the privileged Phnom Penh elite, and their experience of the Khmer Rouge take-over and evacuation of Phnom Penh. The film masterfully depicts the confusion and only slowly materialising realisation of the Khmer Rouge and their ideological plans, as well as the unknown nature of who one should claim to be. At a Khmer Rouge armed checkpoint, the father is uncertain but ultimately denies his own military background, demonstrating well how people struggled initially how to present themselves under the new regime. The family first go to Loung's uncle, but have to move on as the family is worried that the father's identity as a former military person will be uncovered and endanger them all. Eventually, the family is located at a working camp and the film shows the progression of ever harder living and working conditions, as well as the gradual realisation of the totalitarian nature of the regime. As such, the film does justice to the perspective of the girl and her family as the totalitarian nature of the Khmer Rouge regime and coping strategies with this are only discovered throughout the film; it is thus a more realistic depiction of most Cambodians' experience with the regime.

In the course of the film, the family is split up as siblings are re-located to other working camps, the father is taken away (and killed as Loung realises in a dream) and Loung and her remaining siblings flee to other working camps. Loung herself is recruited as a cadre of the Khmer Rouge and is trained in rudimentary military combat and in the political ideologies of the regime; as a Khmer Rouge soldier herself, she then begins to wear her kroma, a traditional scarf worn by

${ }^{1}$ The Killing Fields, directed by Roland Joffé. United Kingdom, 1984. 141 minutes.

Timothy Williams. "Film Review: First They Killed My Father: A Daughter of Cambodia Remembers" Genocide Studies and Prevention 12 , 1 (2018): 113-114. @2018 Genocide Studies and Prevention.

https://doi.org/10.5038/1911-9933.12.1.1595 
all, in the colour red, emblematic for Khmer Rouge cadres at the time. This part of the film shows well the relatively random nature by which many people were simply assigned to be cadres of the Khmer Rouge much like everyone else was also assigned to certain working groups; this coerced assignment of the role underlines the complex nature of living under the regime and alludes to the problematique of complex political perpetrators. ${ }^{2}$ As such, the film continues to portray Loung as a victim of the regime, an attribution that is certainly not wrong, but one that highlights how people could be both victims and perpetrators in this situation of totalitarian control. That the film manages to bring in these nuances of responsibility, agency and victimhood so succinctly is important for an understanding of this period. This is a particularly welcome as it adds nuances of responsibility, agency and victimhood so succinctly into a discussion which has previously primarily portrayed Khmer Rouge cadres as 'evil others' with no attempt to trace their own motivations or their circumstances for joining. Moreover, there is no 'moment' of joining but it is part of a continuum of experiences and part of a fluid transition, so that the viewer does not realise immediately. This resonates with the experiences of many former Khmer Rouge.

The film's next turning point comes with the invasion of Vietnamese troops who Loung does not fight, but instead flees, including through a minefield that she herself had helped lay. At this point, the film takes a Hollywood-esque, sensationalist turn with the fighting between Khmer Rouge troops and Vietnamese, particularly with fleeing people running over mines and exploding. Although the scene is undoubtedly sensationalist and unnecessarily graphic, they are an important reference to the importance of landmines in the conflict and their ongoing impact on the country. Subsequently, Loung is reunited with two of her siblings at a refugee camp where violence between Khmer Rouge and the new government continues, reminding the audience that violence did not leave Cambodia in 1979 when the Khmer Rouge regime was toppled, but that the country remained engulfed by violent civil war well into the 1990s. Later, the siblings are reunited with two more of their brothers and the film ends with a picture of the five of them praying for their lost relatives in a Buddhist temple.

Although the film provides allusions to the broader temporal context within which the story is being told, it follows the lead of most other portrayals and discussions of the Khmer Rouge, seeing 17 April 1975 as the beginning and 7 January 1979 as the end of the Khmer Rouge in Cambodia. This is indeed the period that the Khmer Rouge had control over Phnom Penh and, for the most part, the entire country, but it neglects the civil wars which began in 1970. These civil wars are not only important because they provided incredibly complex dynamics and alliances between political and armed groups, but also because it meant that the population see the period from 1975 until 1979 as only one part of a longer continuum of violence. While a film may not be able to portray everything, its temporal selection plays into the well-rehearsed government narrative and supports its legitimation narrative that is rooted in its liberation of the country from the Khmer Rouge in 1979.

It seems likely that this film will have an important impact on the global memoryscape regarding the genocide by the Khmer Rouge in Cambodia. Notwithstanding sensationalist moments in the cinematography and limited scope in challenging entrenched historical perceptions, the film does provide an important introduction for a broader audience, discusses important topics and offers degrees of nuance on some important issues.

Title of the Film: First They Killed My Father: A Daughter of Cambodia Remembers; Director: Angelina Jolie; Producers: Rithy Panh, Angelina Jolie, Michael Vieira; Screenplay: Angelina Jolie and Loung Ung (based on the book "First They Killed My Father"); Music: Marco Beltrami; Cinematography Anthony Dod Mantle; Film Editors: Xavier Box, Patricia Rommel; Sound Designer: Glenn Freemantle; Cast: Sareum Srey Moch, Phoeung Kompheak, Sveng Socheata, Mun Kimhak, Heng Dara, Khoun Sothea; Country: Cambodia, USA; Language: Khmer, Year of Release: 2017; Production Companies: Netflix, Bophana Production. Duration: 136 minutes.

\footnotetext{
${ }^{2}$ Erin Baines, "Complex Political Perpetrators", The Journal of Modern African Studies 47, no. 2 (2009).
} 